\title{
State of groundwater resource: relationship between its depth and sewage contamination in Leh town of Union Territory of Ladakh
}

\author{
Konchok Dolma ${ }^{1} \mathbb{D} \cdot$ Madhuri S. Rishi ${ }^{2} \cdot$ Renu Lata $^{3}$
}

Received: 28 September 2018 / Accepted: 3 February 2020 / Published online: 21 February 2020

(c) The Author(s) 2020

\begin{abstract}
Groundwater as a resource of wide-spectrum use, especially in the tourism sector, has evolved as the prime most source of water in Leh town in recent years. Unfortunately, the regulation on groundwater use and monitoring as well as scientific management of this resource is almost zero so the resource is over-exploited as well as ill managed. The skewed balance of technology required versus that already available in order to manage this fast urbanizing town is massive, and the place is already showing initial signs of management issues of waste, traffic, air and water pollution. The town is in dire need of innovative and cost-effective solutions for keeping alive its environmental sustainability quotient as it is undergoing a paradigm shift from an agricultural society into a class III urban agglomeration as per Indian Census. In the absence of constant monitoring of this resource, there is a wide data gap related with groundwater resources in Leh town, and so it is very difficult to derive an exact estimation of the water table all over the town. This paper thus gives an elaborate description of the status of groundwater resources in Leh town in dearth of baseline data. Further the risks posed by various factors which are threatening the proper management of this resource are mentioned, and the way forward for sustainable management of Leh town keeping groundwater as a focal point is rightly covered.
\end{abstract}

Keywords Leh town $\cdot$ Urbanization $\cdot$ Water quality $\cdot$ Deterioration

\section{Introduction}

Leh district has come a long way from 527 tourists (1974) to 146,501 tourists (2015) (Statistical Handbook 2015-16) and is ever increasing. Leh town is focal point of this region and bears initial boon or bane of the tourism industry. The success of Bollywood film ' 3 idiots' has immensely contributed in increasing the national tourist influx in addition to international number with more or less stable throughout this period from 2001 to 2011 (Dolma 2015). Simultaneously, the administration carries out various destination promotion events and other marketing attributes like Ladakh Festival

Konchok Dolma

kono20jan@gmail.com

1 Department of Higher Education, Leh, Union Territory of Ladakh 194101, India

2 Department of Environment Studies, Panjab University, Chandigarh, India

3 Himachal Unit, G.B. Pant National Institute of Himalayan Environment and Sustainable Development, Mohal-Kullu, Himachal Pradesh, India for culture and tourism promotion. Also, it cooperates robustly with institutions which organize events like Ladakh International Film Festival (LIFF) which is a cost-effective means of destination marketing without shelling huge sums of monetary resources, thereby saving significant amount of exchequer money. LIFF which was organized in 2012 helped immensely in attracting tourists towards this place. It was a joint effort by the state government of Jammu and Kashmir along with the district administration of Leh. Even the slogan of the festival 'Come explore the magic of Cinema in the magical land of Ladakh' was adopted keeping in mind to promote the destination of Leh as much as possible as an offbeat and out-of-this-world place (Kishore 2013).

In order to support this sector, various resources like land, water and infrastructures are required for smooth and efficient functioning. As tourism is a water-intensive industry, it is highly dependent on groundwater resources of the area. Currently PHE (Public Health Engineering) department of Leh district is supplying 40 lpcd (litres per capita daily) of water to the residents of Leh town, mostly in few summer months through lined water supplies/pipes network. For the rest of the year due to freezing temperatures, bursting of 
pipes occurs and water is supplied through tanker services much lesser than $40 \mathrm{lpcd}$. Water demand increases manifold during summer months due to influx of tourists, and groundwater resources are the only avenue to meet this demand.

Tourism undoubtedly puts acute stress on the quality and quantity of available resources in any booming tourist destination, but adverse stresses are more pronounced in the developing world, where necessary management practices are not followed due to dearth of funds or non-availability of cost-effective technologies. Furthermore with quantityfocused stress, there is an even greater risk of quality deterioration through contamination of groundwater, especially in areas where waste water treatment is inadequate or not at all available. The town of Leh is adopting water-intensive flush toilets and constructing soak pits for waste water disposal in the absence of any sewerage system which is a major shift from an age-old traditional dry sanitation practice. In such a case, the threat of shallow groundwater pollution is enormous in the town as the sewerage system being laid currently is only partial and will take years to fully function.

\section{Study area}

The land of Ladakh is so barren and passes so high that it was almost cut off from the rest of the Indian mainland. Since ancient times, Ladakh was an agricultural society, but northern Leh town of India located near key mountain passes was a trading network hub, even during those times. Leh town was a part of the great trading Silk Route which connected Central Asia, South Asia and Tibet, but this route was opened only during summers and cut off during winters due to heavy snow. So, this town was an important resting location for trading troupes, especially during summers, but this scenario was true to core before independence of India. After closing off of the two borders with China and Pakistan, Leh town was transformed into a remote cut-off place in popular Indian psyche. With the closing of centuries' famous trade route known popularly as the Silk Route, Leh town took a U-turn from a cosmopolitan outlook towards one of the remotest places in India (Fewkes 2012).

Ladakh region is a high-altitude 'Cold Desert' in the north of India in Jammu and Kashmir state which consists of Leh and Kargil districts before passing of J\&K Reorganization Act on 31st October 2019 in the Indian Parliament. After passing of act, the cold desert of Ladakh became Union Territory of Ladakh and as of present is being administered directly by the Central Government of India. Cold deserts are usually confined to high altitude and circumpolar regions. Ladakh is the largest cold desert zone in TransHimalayas (Ballabh et al. 2007). It is blessed with the most beautiful and highest lakes like Pangong and Tsomoriri and enchanting valleys like Indus and Suru. Its glaciers, glaciated topography, steep gorges, cataracts, alluvial fans, river terraces and socio-cultural milieu present large potential for explorers, trekkers, leisure-seekers and academicians (Jina 1994). This land is also popularly known as land of high rising passes or 'Little Tibet' (Gairola et al. 2014). The famed Nubra valley lies in Ladakh, and this name in local dialect 'Dumra' literally translates into garden or green valley (Joshi et al. 2005). Nubra also has vast vegetation characteristics like scattered low bushes, sparsely covered tussock grasslands, herbaceous formation, sedge meadows and stony deserts (Joshi et al. 2006). Ladakh and Karakoram ranges have been an area of attraction for earth scientists as well, to study the dynamic relationship between Indian and Eurasian plates (Pant et al. 2005).

Only in 1974 when the region was partially opened for tourism, this area was truly opened for explorers from rest of the world. Leh town being the main administrative centre and having air connectivity year round has a booming tourism industry in the present times. Earlier, agriculture was the main source of livelihood in this region which in current times is getting a respite from other economic avenues like tourism industry and jobs created by this sector. Another imminent sector of economic opportunities is created recently due to large permanent deployment of Indian army personnel. Enhanced acceptance of strategic location and importance of this region in maintaining regional hegemony is fully supported by Government of India. This area has the famed Siachen glacier which is a vantage point for India and its security.

\section{Leh town}

The patterns of settlements in Leh district are mainly located in between the river valleys situated below the mighty Himalayan mountains, and these valleys are formed especially due to erosional activities of glaciers, located in between these mountain ranges from millennia. Leh valley is a U-shaped valley formed due to such erosional activities and morainic deposits that underlie the plain consisting of boulders, cobbles, pebbles embedded in an arenaceous matrix and lake deposits comprising predominantly of clays, sandy clays and silt, indicating remains of lake deposits (CGWB 2009). Leh town lies in Leh valley lying between $34^{\circ} 8^{\prime} \mathrm{N}$ to $34^{\circ} 13^{\prime} \mathrm{N}$ latitude and $77^{\circ} 32^{\prime} \mathrm{E}$ to $77^{\circ} 38^{\prime} \mathrm{E}$ longitude totalling an area of $9.15 \mathrm{~km}^{2}$ (Fig. 1).

\section{Methodology}

In order to successfully carry out the proposed study, a scientific and thoroughly tested methodology which is technically sound was adopted. A total of 30 water 


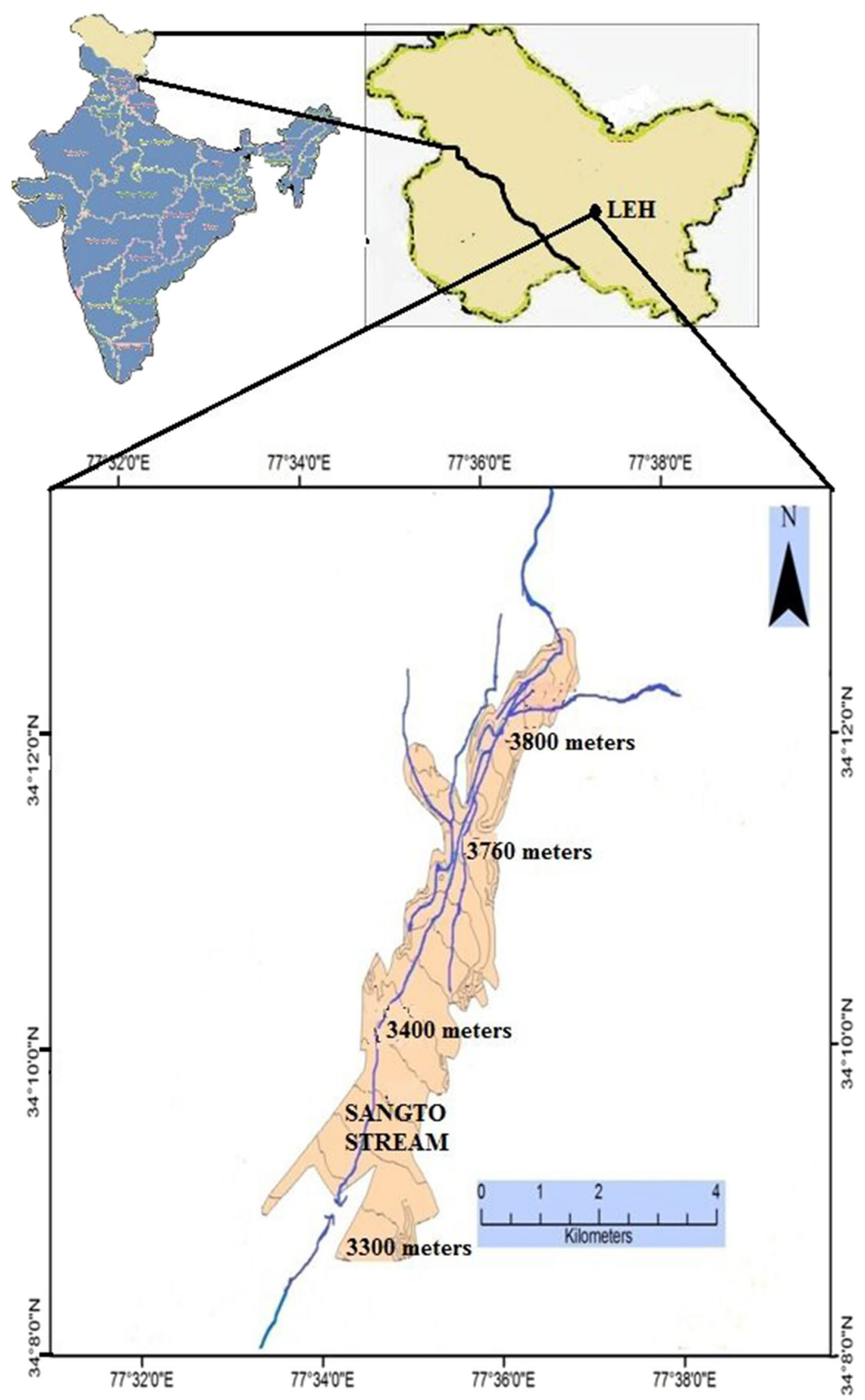

Fig. 1 Location of Leh town, the study area 
samples especially from groundwater were collected from bore wells, springs and from hand pumps in the pre-monsoon season month of May (2013 and 2014) and post-monsoon season month of October (2013 and 2014) which coincided with the pre- and post-monsoon season months simultaneously, so as to evaluate its fitness for drinking purposes and other domestic uses. The groundwater samples were analysed in physicochemical laboratory of Geology Department, Panjab University. The water samples were characterized for various parameters in accordance with the standard methodology given by APHA (2005) for both the seasons (Tables 1, 2). Parameters like $\mathrm{Na}^{+}, \mathrm{K}^{+}, \mathrm{Cl}^{-}, \mathrm{SO}_{4}{ }^{2-}$ were converted into meq/l by multiplying with their respective standard multiplying factors. Further, $r 1$ (Base-Exchange) and $r 2$ (Meteoric Genesis Indices) were evaluated from the above data in meq/l. Totally, 30 samples of groundwater were taken from all over Leh town and its fringe areas located in Leh district of the Union Territory of Ladakh (Fig. 2).

\section{Data deficient on groundwater lithology and classification based on base-exchange and meteoric genesis index}

(r1) Base-exchange: Groundwater properties, on the basis of predominantly consisting chemicals, particularly $\mathrm{Na}^{+}-\mathrm{SO}_{4}{ }^{2-}$ and $\mathrm{Na}^{+}-\mathrm{HCO}_{3}{ }^{-}$types, were classified according to the above two types. The equation to calculate $(r 1)$ base-exchange is as follows:

Table 1 Results of groundwater sample analysis during pre-monsoon/pre-tourist season

\begin{tabular}{|c|c|c|c|c|c|c|c|c|c|c|c|c|c|c|c|c|}
\hline S. no. & Location & $\begin{array}{l}\mathrm{pH} \\
(\mu \mathrm{S} /\end{array}$ & & TDS & $\mathrm{TH}$ & $\mathrm{Ca}^{2+}$ & $\mathrm{Mg}^{2+}$ & $\begin{array}{l}\mathrm{Na}^{+} \\
(\mathrm{mg} / \mathrm{l})\end{array}$ & $\mathrm{K}^{+}$ & $\mathrm{CO}_{3}{ }^{2-}$ & $\mathrm{HCO}_{3}^{-}$ & $\mathrm{Cl}^{-}$ & $\mathrm{F}^{-}$ & $\mathrm{NO}_{3}{ }^{-}$ & $\mathrm{SO}_{4}{ }^{2-}$ & WQI \\
\hline 1 & Gyalung & 7.6 & 223 & 146 & 100 & 53.64 & 9.88 & 7.1 & 3.3 & BDL & 52 & 8 & BDL & 0.44 & 7.94 & 34.81 \\
\hline 2 & Gangles & 7 & 210 & 140 & 80 & 52.6 & 22.45 & 8.7 & 3.2 & BDL & 33 & 5.1 & BDL & 1.8 & 36.45 & 19.87 \\
\hline 3 & Gompa & 7 & 283 & 186 & 110 & 54.48 & 11.83 & 9 & 3 & BDL & 16 & 5.1 & BDL & 0.01 & 6.01 & 12.68 \\
\hline 4 & Sankar & 7 & 205 & 134 & 90 & 45.23 & 12.32 & 8 & 5.1 & BDL & 59 & 10 & BDL & 5 & 5.4 & 12.35 \\
\hline 5 & Yourtung & 7 & 234 & 160 & 200 & 72.8 & 20.04 & 7 & 4.7 & BDL & 27 & 12 & BDL & 0.01 & 8.67 & 19.43 \\
\hline 6 & Khagshal & 7.5 & 256 & 168 & 190 & 80 & 16.68 & 17 & 4.9 & BDL & 152 & 16 & BDL & 0.01 & 28.45 & 39.06 \\
\hline 7 & Changspa & 7.2 & 287 & 187 & 132 & 52.8 & 18.17 & 7.1 & 3.2 & BDL & 28 & 10 & BDL & 0 & 5.4 & 23.87 \\
\hline 8 & Chubi & 7.5 & 248 & 308 & 100 & 52.8 & 10.37 & 15.1 & 5.9 & BDL & 139 & 14 & BDL & 0 & 6.08 & 31.73 \\
\hline 9 & LEDeG & 7.1 & 275 & 159 & 120 & 53.64 & 14.76 & 6.5 & 3.2 & BDL & 62 & 5 & BDL & 0.2 & 6.1 & 18.25 \\
\hline 10 & Karzoo & 7 & 303 & 199 & 114 & 56.16 & 11.83 & 7.2 & 3.5 & $\mathrm{BDL}$ & 40 & 7 & BDL & 0 & 5.4 & 12.95 \\
\hline 11 & U.Tuckha & 7.2 & 439 & 166 & 92 & 53.64 & 7.93 & 6.6 & 3.6 & BDL & 132 & 5.1 & $\mathrm{BDL}$ & 0 & 5.4 & 18.50 \\
\hline 12 & Middle Sch & 8 & 387 & 260 & 200 & 84 & 19.02 & 6.2 & 4.3 & BDL & 38 & 12.1 & BDL & 0.01 & 19.08 & 59.23 \\
\hline 13 & Fort Road & 7.5 & 549 & 361 & 188 & 57.85 & 28.91 & 10.3 & 3.4 & BDL & 52 & 6.4 & $\mathrm{BDL}$ & 1 & 9.01 & 42.76 \\
\hline 14 & Shenam & 7 & 324 & 250 & 140 & 58.69 & 16.71 & 9.2 & 4.3 & BDL & 56 & 5.6 & BDL & 0 & 5.4 & 16.13 \\
\hline 15 & 16BRTF & 7.1 & 295 & 194 & 110 & 59.53 & 8.9 & 17 & 3.3 & BDL & 112 & 18 & BDL & 0.22 & 5.4 & 15.85 \\
\hline 16 & Zorawar Ft & 7.5 & 424 & 270 & 150 & 56.42 & 14.56 & 10.5 & 3.7 & $\mathrm{BDL}$ & 84 & 13 & $\mathrm{BDL}$ & 5.07 & 48.17 & 36.92 \\
\hline 17 & Skara Spring & 7.6 & 575 & 202 & 134 & 41.87 & 25 & 15.3 & 3.9 & BDL & 41 & 2.97 & BDL & 0.12 & 9.5 & 42.39 \\
\hline 18 & Skalzangling & 8 & 403 & 269 & 100 & 58.64 & 8.8 & 10.9 & 7.6 & BDL & 62 & 9.67 & BDL & 10.05 & 11.06 & 51.09 \\
\hline 19 & Housing $\mathrm{Cl}$ & 7 & 849 & 393 & 170 & 55.32 & 25.98 & 20.8 & 4.8 & BDL & 40 & 26 & BDL & 0 & 9.7 & 21.79 \\
\hline 20 & DIHAR & 7.5 & 660 & 434 & 142 & 40.19 & 27.93 & 16.1 & 3.6 & BDL & 92 & 14 & BDL & 0 & 6.63 & 40.62 \\
\hline 21 & Murtse & 7.1 & 357 & 236 & 170 & 56.46 & 14.06 & 8.47 & 3.7 & $\mathrm{BDL}$ & 48 & 7.71 & BDL & 0.01 & 8.01 & 18.62 \\
\hline 22 & Ibex Colony & 7 & 423 & 279 & 156 & 63.73 & 17.68 & 7.6 & 3.8 & $\mathrm{BDL}$ & 36 & 6.9 & BDL & 0.5 & 6.76 & 17.30 \\
\hline 23 & ITBP Leh & 7.7 & 351 & 230 & 170 & 80.37 & 16.09 & 10.8 & 4.8 & $\mathrm{BDL}$ & 112 & 12.3 & BDL & 3.07 & 21.47 & 46.11 \\
\hline 24 & MES IIIrd & 7.5 & 347 & 231 & 144 & 65.42 & 13.78 & 7.1 & 3.3 & BDL & 98 & 10 & BDL & 0 & 5.39 & 34.58 \\
\hline 25 & MES Spituk & 7.5 & 482 & 317 & 178 & 55.32 & 27.93 & 12.1 & 4.3 & BDL & 108 & 9 & BDL & 0 & 5.85 & 41.86 \\
\hline 26 & Airforce Stn & 7.6 & 200 & 137 & 150 & 62.87 & 12.03 & 7.6 & 4.4 & BDL & 88 & 9.34 & $\mathrm{BDL}$ & 3.07 & 28.45 & 38.45 \\
\hline 27 & CIBS & 7.5 & 301 & 198 & 167 & 67.21 & 29.07 & 8.7 & 4.6 & BDL & 98 & 9.23 & $\mathrm{BDL}$ & 2.8 & 21.45 & 44.16 \\
\hline 28 & Zivey Tsal & 7.7 & 835 & 431 & 130 & 31.77 & 29.88 & 36.9 & 5.2 & $\mathrm{BDL}$ & 136 & 4.2 & $\mathrm{BDL}$ & 0 & 26.23 & 49.80 \\
\hline 29 & Choglamsar & 8 & 496 & 326 & 164 & 48.6 & 28.42 & 22.6 & 3.4 & BDL & 142 & 5.1 & BDL & 0 & 18.01 & 61.52 \\
\hline 30 & SOS Village & 7.6 & 367 & 240 & 250 & 76.21 & 26.08 & 26.6 & 6.6 & BDL & 162 & 16.3 & BDL & 0.01 & 28.51 & 48.25 \\
\hline
\end{tabular}

$B D L$ below detectable limit 
Table 2 Results of groundwater sample analysis during post-monsoon/post-tourist season

\begin{tabular}{|c|c|c|c|c|c|c|c|c|c|c|c|c|c|c|c|c|}
\hline S. no. & Location & $\begin{array}{l}\mathrm{pH} \\
(\mu \mathrm{S} /\end{array}$ & $\begin{array}{l}\text { EC } \\
\text { m) }\end{array}$ & TDS & $\mathrm{TH}$ & $\mathrm{Ca}^{2+}$ & $\mathrm{Mg}^{2+}$ & $\begin{array}{l}\mathrm{Na}^{+} \\
(\mathrm{mg} / \mathrm{l})\end{array}$ & $\mathrm{K}^{+}$ & $\mathrm{CO}_{3}{ }^{2-}$ & $\mathrm{HCO}_{3}^{-}$ & $\mathrm{Cl}^{-}$ & $\mathrm{F}^{-}$ & $\mathrm{NO}_{3}^{-}$ & $\mathrm{SO}_{4}{ }^{2-}$ & WQI \\
\hline 1 & Gyalung & 7.6 & 220 & 131 & 94 & 51.11 & 9.88 & 7.5 & 3 & BDL & 51 & 9 & BDL & 0.42 & 6.01 & 32.59 \\
\hline 2 & Gangles & 7.4 & 190 & 130 & 90 & 52 & 23 & 8 & 3.5 & BDL & 30 & 2.5 & BDL & 1.5 & 36.03 & 32.63 \\
\hline 3 & Gompa & 7.1 & 260 & 172 & 100 & 51.2 & 12.83 & 9.2 & 3.1 & BDL & 16 & 3.1 & BDL & 0 & 6.5 & 15.66 \\
\hline 4 & Sankar & 7.5 & 201 & 130 & 80 & 41.87 & 13.6 & 7.9 & 5.2 & BDL & 52 & 9.1 & BDL & 7.1 & 4.8 & 31.54 \\
\hline 5 & Yourtung & 7 & 220 & 150 & 194 & 70.01 & 19.2 & 7.3 & 4.2 & BDL & 28 & 11.5 & BDL & 0.02 & 7.1 & 17.41 \\
\hline 6 & Khagshal & 7.5 & 270 & 180 & 180 & 74.6 & 16.01 & 17 & 5.2 & BDL & 143 & 12 & BDL & 0.01 & 27.23 & 34.97 \\
\hline 7 & Changspa & 8 & 280 & 178 & 122 & 45.23 & 20.12 & 6.3 & 3.1 & BDL & 24 & 10 & BDL & 0 & 4.01 & 52.24 \\
\hline 8 & Chubi & 7.6 & 220 & 151 & 98 & 41.02 & 11.71 & 15.5 & 5.7 & BDL & 135 & 15 & BDL & 0 & 5.3 & 33.42 \\
\hline 9 & LEDeG & 7.2 & 262 & 171 & 112 & 43.55 & 15.66 & 6.7 & 3 & BDL & 61 & 4.5 & BDL & 2.77 & 5.7 & 20.96 \\
\hline 10 & Karzoo & 8 & 300 & 186 & 120 & 51.96 & 10.85 & 7 & 3.3 & BDL & 40 & 6.4 & BDL & 0.3 & 4.6 & 48.05 \\
\hline 11 & U.Tuckha & 8 & 400 & 269 & 72 & 50.27 & 8.416 & 6.1 & 3.1 & BDL & 127 & 4.4 & BDL & 0.5 & 3.7 & 46.75 \\
\hline 12 & Middle Sch & 8 & 340 & 231 & 198 & 87 & 19.56 & 6.6 & 4.5 & BDL & 37 & 11.8 & $\mathrm{BDL}$ & 0 & 18.01 & 56.14 \\
\hline 13 & Fort Road & 7.4 & 529 & 320 & 172 & 53.64 & 34.01 & 9.8 & 3.7 & BDL & 46 & 5.2 & BDL & 1 & 8.47 & 38.97 \\
\hline 14 & Shenam & 7 & 365 & 237 & 130 & 52.8 & 22.68 & 8.9 & 3.9 & BDL & 53 & 5 & BDL & 0 & 4.8 & 17.61 \\
\hline 15 & 16BRTF & 7.6 & 286 & 186 & 100 & 53.64 & 9.88 & 16 & 3.1 & BDL & 111 & 17.2 & BDL & 0.5 & 4.2 & 33.12 \\
\hline 16 & Zorawar Ft & 7.2 & 387 & 255 & 137 & 53 & 15 & 9.5 & 3.9 & BDL & 80 & 12.3 & BDL & 4.8 & 46.67 & 22.77 \\
\hline 17 & Skara Spring & 7.5 & 556 & 369 & 112 & 38.5 & 26.6 & 14.4 & 3.6 & BDL & 40 & 1.34 & BDL & 0.1 & 7.8 & 37.13 \\
\hline 18 & Skalzangling & 7.1 & 390 & 259 & 102 & 60 & 8.1 & 11.2 & 7.3 & BDL & 62 & 8.01 & BDL & 9.5 & 10.8 & 16.50 \\
\hline 19 & Housing $\mathrm{Cl}$ & 7.2 & 826 & 560 & 150 & 52 & 23.05 & 18.8 & 4.1 & BDL & 35 & 25.4 & BDL & 0.01 & 8.1 & 26.06 \\
\hline 20 & DIHAR & 7.6 & 568 & 412 & 138 & 35.13 & 29.88 & 15.1 & 3.1 & BDL & 93 & 13.7 & BDL & 0.01 & 5.01 & 42.52 \\
\hline 21 & Murtse & 7.1 & 360 & 243 & 176 & 58 & 15 & 8.5 & 3.9 & BDL & 48 & 6.4 & BDL & 0 & 7.96 & 18.01 \\
\hline 22 & Ibex Colony & 7.4 & 411 & 256 & 138 & 60.37 & 15.24 & 7.2 & 3.2 & BDL & 51 & 9 & BDL & 0.42 & 6.01 & 29.89 \\
\hline 23 & ITBP Leh & 7.3 & 302 & 200 & 172 & 77 & 17.01 & 10.03 & 4.9 & BDL & 35 & 6.3 & BDL & 3.18 & 5.43 & 28.89 \\
\hline 24 & MES IIIrd & 7.7 & 321 & 212 & 134 & 59.52 & 14.76 & 6.8 & 3 & BDL & 113 & 11.5 & BDL & 3.05 & 19.98 & 39.87 \\
\hline 25 & MES Spituk & 7.4 & 461 & 306 & 152 & 50.27 & 25.52 & 11.2 & 4.1 & BDL & 93 & 9.4 & BDL & 0.01 & 4.7 & 33.98 \\
\hline 26 & Airforce Stn & 7.2 & 210 & 145 & 154 & 65.07 & 12.16 & 8.2 & 4 & BDL & 110 & 7.8 & BDL & 0.01 & 4.3 & 21.45 \\
\hline 27 & CIBS & 8.1 & 501 & 180 & 158 & 58.76 & 28.02 & 10.1 & 3.2 & BDL & 85 & 8.24 & BDL & 3 & 25.56 & 62.21 \\
\hline 28 & Zivey Tsal & 7.6 & 820 & 510 & 120 & 30.09 & 28.42 & 32.8 & 4.7 & BDL & 100 & 8.65 & BDL & 2.1 & 20.8 & 41.74 \\
\hline 29 & Choglamsar & 8 & 488 & 316 & 142 & 42.7 & 26.47 & 20.6 & 3 & BDL & 133 & 4.3 & BDL & 0.04 & 25.78 & 56.08 \\
\hline 30 & SOS Village & 7.4 & 356 & 235 & 220 & 72.1 & 27.3 & 25.9 & 6.1 & BDL & 143 & 4.8 & BDL & 0.01 & 16.89 & 37.38 \\
\hline
\end{tabular}

$B D L$ below detectable limit

$r 1=\left(\mathrm{Na}^{+}-\mathrm{Cl}^{-}\right) / \mathrm{SO}_{4}^{2-}$.

Now, the index of base-exchange is denoted by $r 1$, and in meql/l the various concentrations of $\mathrm{Na}^{+}, \mathrm{Cl}^{-}$and $\mathrm{SO}_{4}{ }^{2-}$ ions are depicted. The sources of groundwater are of $\mathrm{Na}^{+}-\mathrm{SO}_{4}{ }^{2-}$ type when $r 1<1$, and also the sources of groundwater are $\mathrm{Na}^{+}-\mathrm{HCO}_{3}{ }^{-}$type when $r 1>1$. As per $(r 1)$, base-exchange index types about $56.66 \%$ and $43.33 \%$ samples of water of groundwater were categorized as $\mathrm{Na}^{+}-\mathrm{SO}_{4}{ }^{2-}$ type, whereas $43.33 \%$ and $56.66 \%$ were classified in $\mathrm{Na}^{+}-\mathrm{HCO}_{3}{ }^{-}$during pre- and post-tourist seasons, respectively, which is also coinciding with pre- and post-monsoon seasons simultaneously. This could be attributed to the geological formations through which groundwater has traversed (Table 3). (r2) Meteoric genesis indices: (Soltan 1998) As per meteoric genesis indices, groundwater can be categorized into two types after calculating from the below equation:

$r 2=\left[\left(\mathrm{Na}^{+}+\mathrm{K}^{+}\right)-\mathrm{Cl}^{-} / \mathrm{SO}_{4}^{2-}\right]$

The index of meteoric genesis is indicated by $r 2$, and in meq/l the concentrations of $\mathrm{Na}^{+}, \mathrm{K}^{+}, \mathrm{Cl}^{-}$and $\mathrm{SO}_{4}{ }^{2-}$ are evaluated. In case of deep meteoric water percolation type, $r 2<1$, and in case of shallow meteoric water percolation type, $r 2>2$.

As per this index, the sources of water of groundwater that is $56.66 \%$ and $70 \%$ during pre- and post-monsoon, respectively, were categorized as shallow meteoric water percolating type. Also, $43.33 \%$ and $30 \%$ of the remaining samples of groundwater out of the total 30 samples 


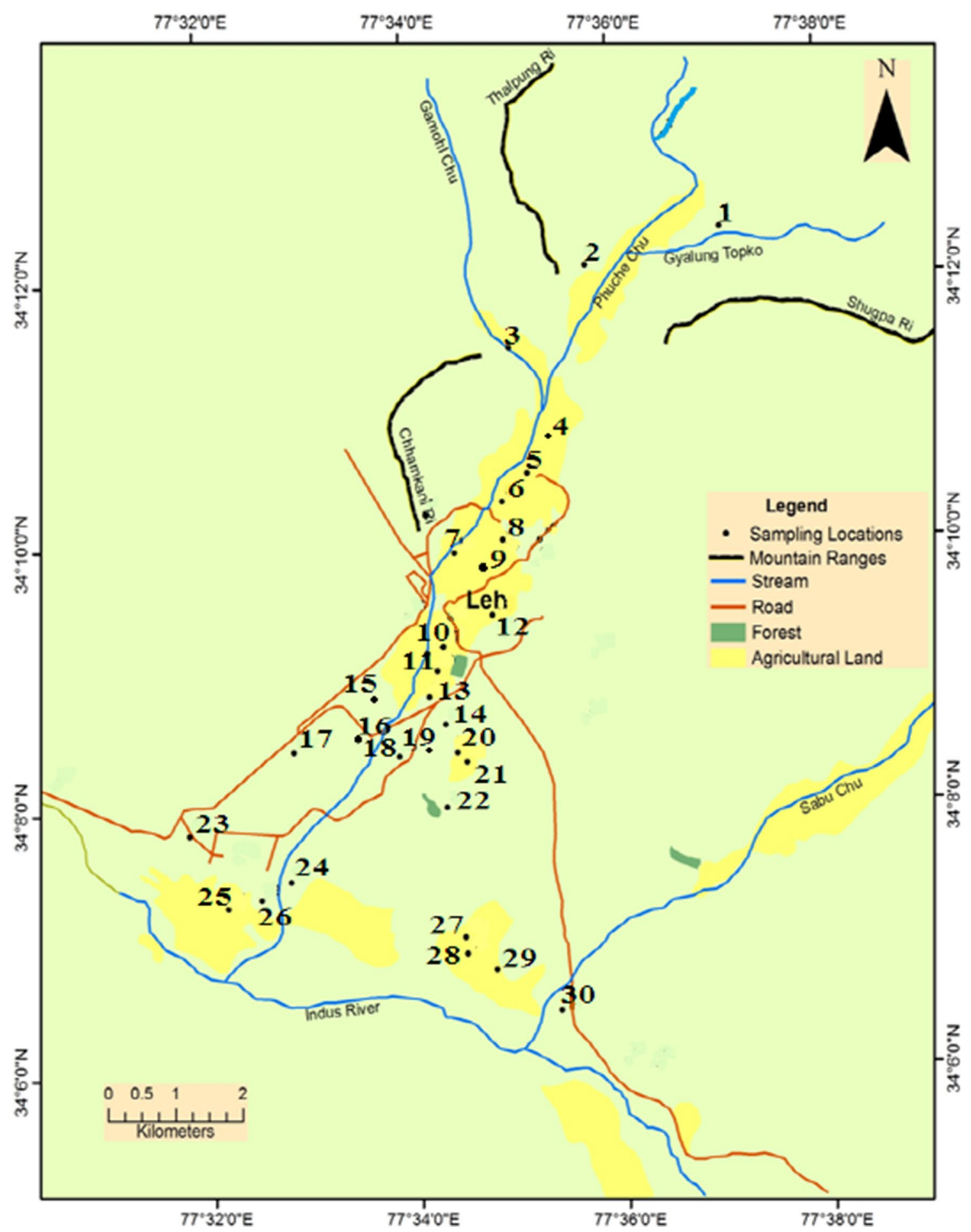

Fig. 2 Location map of groundwater sampling sites

were categorized as deep meteoric percolating water type simultaneously during pre- and post-monsoon seasons, respectively (Table 3 ).
Threat of contamination from raw sewage pollution in the shallow groundwater source points in Leh town

Frequent present/absent testing for faecal contamination is conducted in the main district hospital from various 


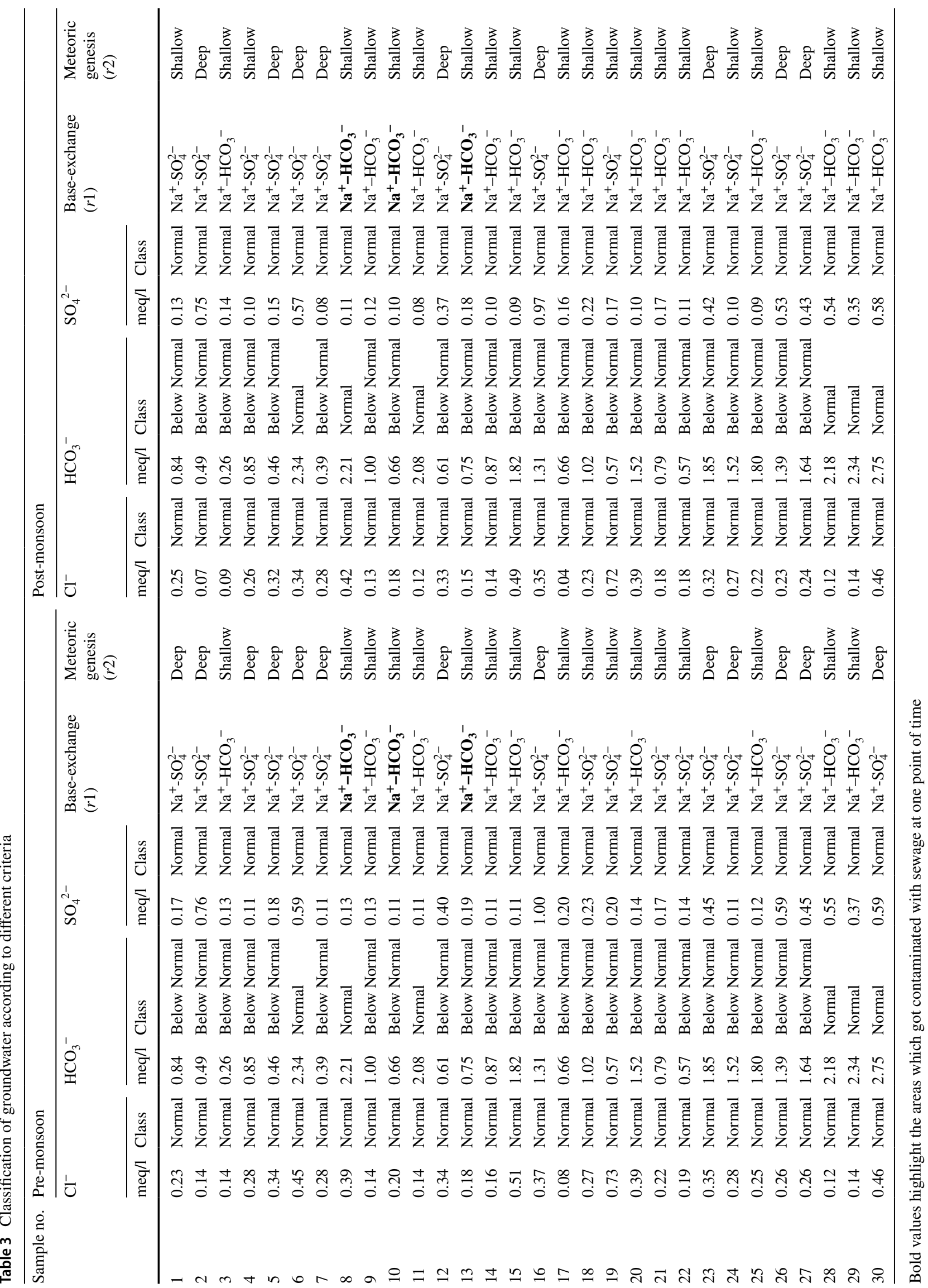


urbanized parts of the region, but threat from point sources of raw sewage disposal from flush toilets is evident with the detection of coliform bacteria in post-tourist season in 2013 in a drinking water source from a hand pump in Chubi area of Leh town which was tapped from an earlier artesian spring confirmed during reconnaissance survey.

According to Table 3, sample no. 8, which is Chubi hand pump, falls in the shallow meteoric genesis of water source, thus indicating shallow origin even though in 2013 pre-tourist season and both pre- and post-tourist seasons in 2014 no bacterial presence was detected out of the 30 groundwater samples analysed through standard procedures (APHA 2005) in Leh town. Exhaustive data unavailability regarding borewell lithological units and point sewage pollution sources are major hindrances in concluding any relationship. In spite of large data being absent, this contamination incident might indicate the intermittent dependence on point sources of pollution in contamination of shallow spring sources. There are many non-reported cases where earlier natural springs in spite of non-drying but due to rare cases of sewage contamination are now shunned by locals. These incidents were found during the reconnaissance phase of this study ultimately indicating threats of raw sewage disposal and groundwater pollution issues, especially shallow sources of groundwater. Some of the groundwater sources which reported incidents of water contamination with raw sewage at any point of time in past several years surprisingly fall in shallow meteoric genesis indices which are mentioned in Table 4.

The contamination incidents and their locations all falling in shallow groundwater zones indicate threat of sewage pollution in such sources of groundwater and the looming crisis of sewage management, in the event of an STP plant still under construction phase in Leh town. The sample numbers, 10 and 13 were not detected with faecal contamination in either 2013 or 2014, but the above incidents of sewage contamination were acknowledged by the residents in 2013 during a reconnaissance survey undertaken in that year. Tourism undoubtedly puts acute stress on the quality and quantity of available resources in any booming tourist destination, but adverse stresses are more pronounced in the developing world where necessary management practices are not followed due to dearth of funds or non-availability

Table 4 Contaminated groundwater sources and their depths

\begin{tabular}{llll}
\hline Sample no & Location & $\begin{array}{l}\text { Year of sewage } \\
\text { contamination }\end{array}$ & $\begin{array}{l}\text { Meteoric } \\
\text { genesis } \\
(r 1)\end{array}$ \\
\hline 8 & Chubi & 2013 & Shallow \\
10 & Karzoo & 1999 & Shallow \\
13 & Fort Road & 2011 & Shallow \\
\hline
\end{tabular}

of cost-effective technologies. Furthermore with quantityfocused stress, there is an even greater risk of quality deterioration through contamination of groundwater, especially in areas where waste water treatment is inadequate or not available. The town of Leh is adopting water-intensive flush toilets and constructing soak pits for waste water disposal in the absence of any sewerage system which is a major shift from an age-old traditional dry sanitation practice. In such a case, the threat of shallow groundwater pollution is enormous.

\section{Groundwater chemistry controlled by certain mechanisms}

A diagram was proposed by Gibbs (1970) to derive a link between the chemical compositions of groundwater as per the aquifer lithologies in which they were confined. In order to get a deeper grasp and understanding of the various processes of chemical interaction of water within the aquifer lithologies like precipitation rock-water interaction and evaporation on the chemistry of groundwater in the concerned study area, the plot given by Gibbs was used. He further showed that if TDS (total dissolved solids) is pointed with respect to $\left(\mathrm{Na}^{+}+\mathrm{K}^{+}\right) /\left(\mathrm{Na}^{+}+\mathrm{K}^{+}+\mathrm{Ca}^{+}\right)$concentration, it will show the controlling mechanism of groundwater chemistry. The chemistry of groundwater is regulated by major mechanisms, three in total particularly: (a) Evaporation, (b) Precipitation and (c) Rock dominance.

The following equations given below are used to calculate Gibbs ratios:

(Cation) Gibbs ratio $\mathrm{I}=\left[\left(\mathrm{Na}^{+}+\mathrm{K}^{+}\right) /\left(\mathrm{Na}^{+}+\mathrm{K}^{+}+\mathrm{Ca}^{+}\right)\right]$ (Anion) Gibbs ratio $\mathrm{II}=\left[\mathrm{Cl}^{-} /\left(\mathrm{Cl}^{-}+\mathrm{HCO}_{3}^{-}\right)\right]$

whereas in meq/l the concentration of ions is evaluated.

Gibbs ratio is calculated separately for anions and cations. Gibbs ratios of water samples are plotted against their respective total dissolved solids to assess the functional sources of dissolved chemical constituents in groundwater, as shown in Figs. 3 and 4, for pre- and post-monsoon seasons, respectively.

The anions and cations for Gibbs ratios for both pre-monsoon and post-monsoon seasons are described in the above figures. A glance and interpretation from the above figures give an indication that the groundwater samples of the study area lie in the rock dominance zone. This establishes the fact that a strong interaction is present among the lithological units of aquifer where the groundwater is present and the groundwater encompassing that lithological space.

Hence, it can be derived that carbonate weathering processes are responsible for the type of groundwater chemistry in the study region. 


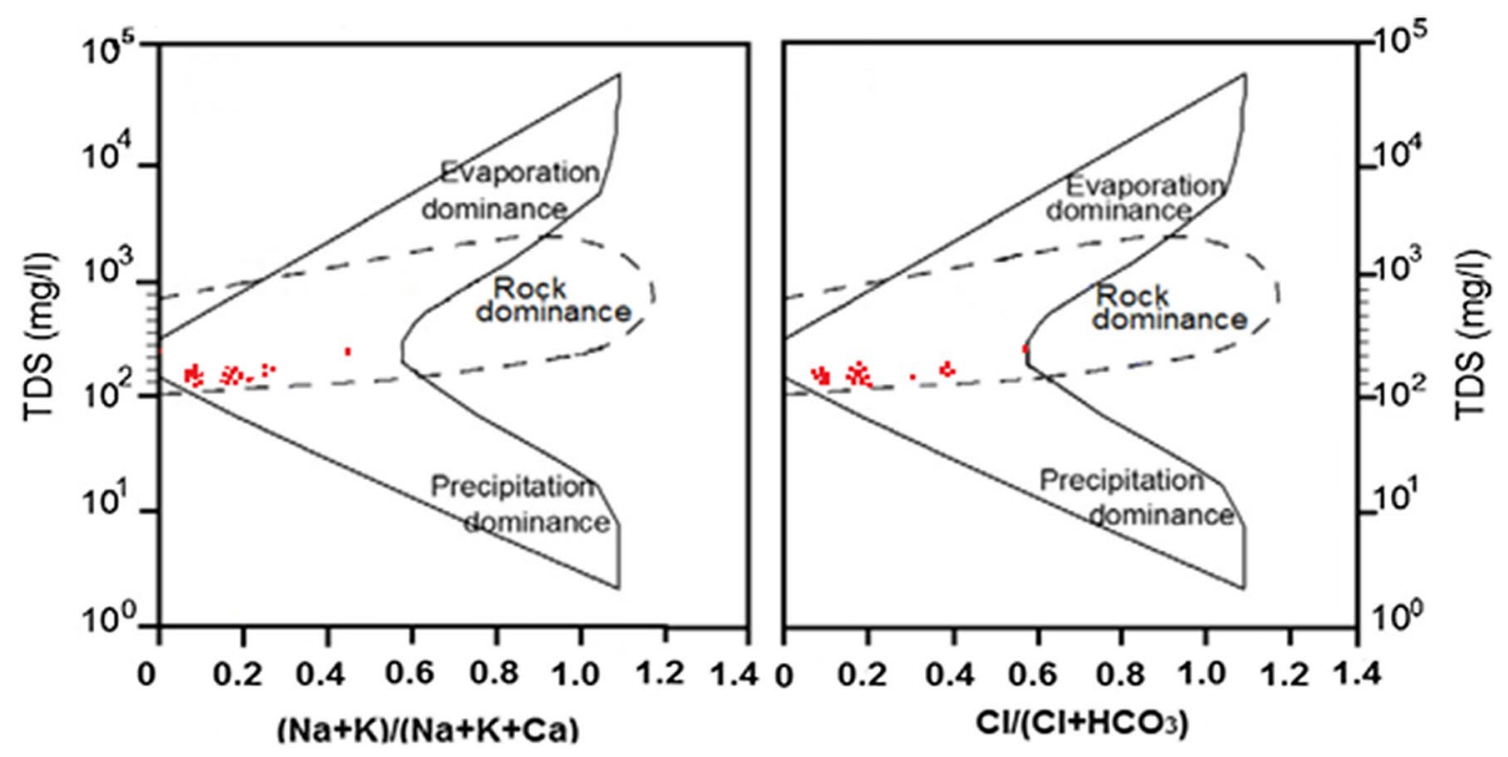

Fig. 3 Gibbs ratio for groundwater in pre-monsoon
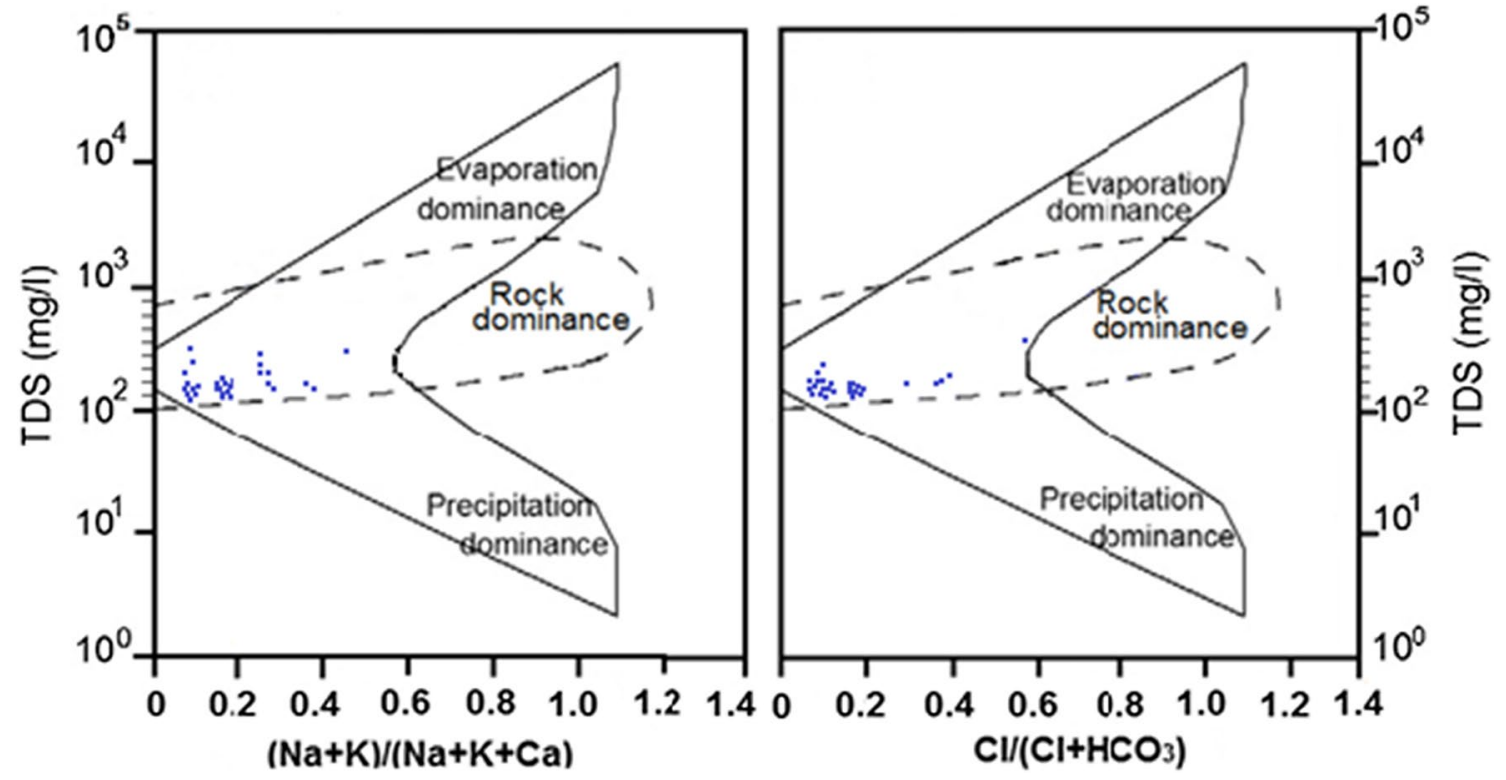

Fig. 4 Gibbs ratio for groundwater in post-monsoon

\section{Hydrochemical facies}

The evolutionary aspects of water resources can be known by the hydrochemical diagrams. Along with groundwater quality distribution and the sections of hydrochemical aspects of water samples give a broad spectrum of the water characteristics of the study area. Here, the chemical processes due to mixing with the lithological units are shown aptly through the facies, and the graphical representation makes it easy to comprehend (Todd 1980).

\section{Hill-Piper trilinear diagram}

Hill-Piper trilinear diagram was used to plot the results of water analysis and to get an idea about the hydrochemical regime of resources of groundwater in the research area (Piper 1944) (Figs. 5, 6). Differences and similarities among the analysed water samples are clearly demarcated in the Piper-Hill diagram as the plotted together water samples in the diagram are of similar hydrochemical properties and those which are scattered are of different 


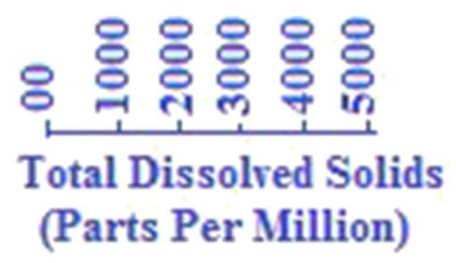

Piper Diagram

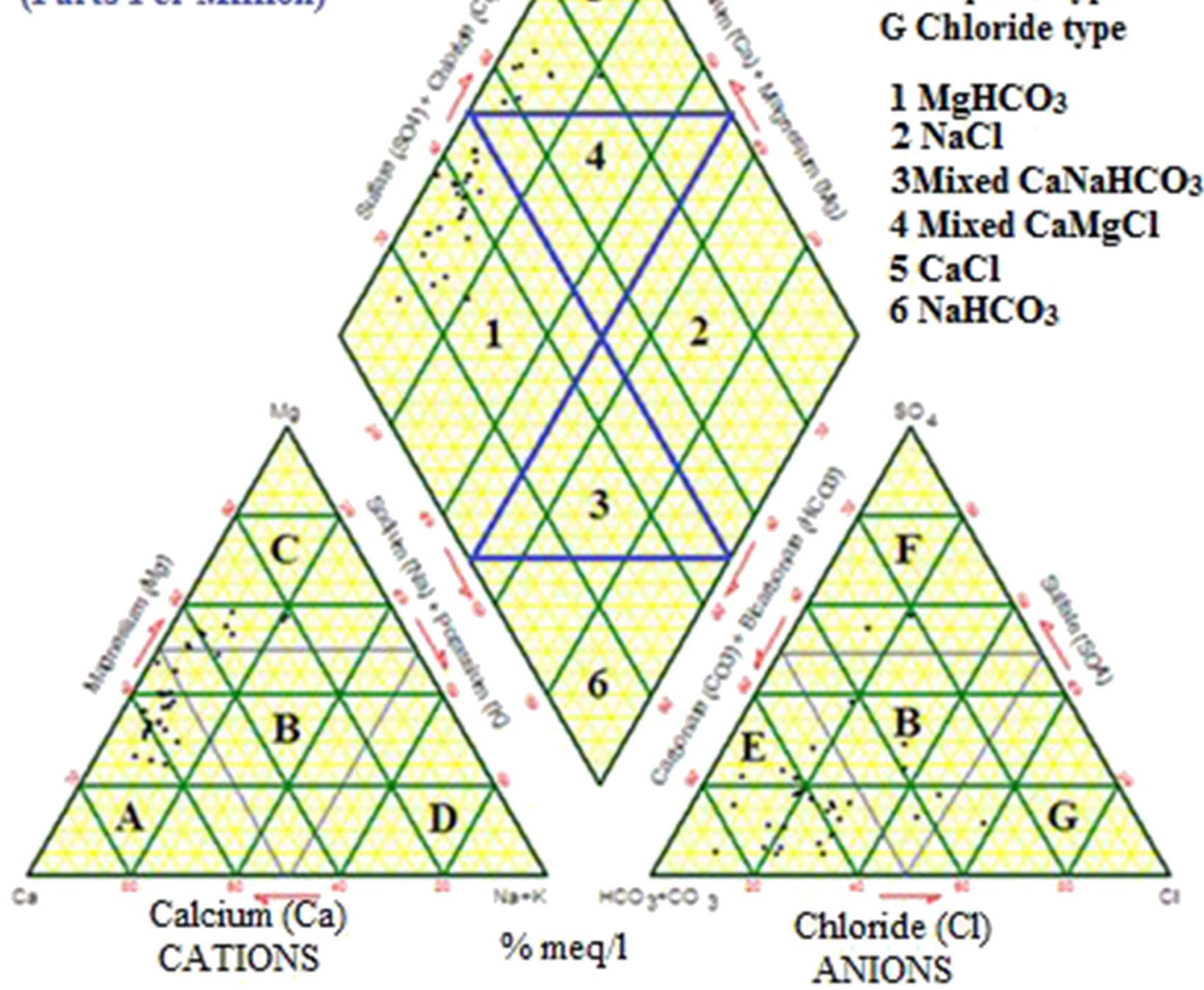

\section{A Calcium type \\ B No dominant}

C Magnesium type

D Sodium type

E Bicarbonate type

F Sulphate type

G Chloride type

$1 \mathrm{MgHCO}_{3}$

$2 \mathrm{NaCl}$

3 Mixed $\mathrm{CaNaHCO} 3$

4 Mixed $\mathrm{CaMgCl}$

$5 \mathrm{CaCl}$

$6 \mathrm{NaHCO}_{3}$

Fig. 5 Piper classification diagram illustrating the chemical composition of groundwater in pre-monsoon

properties. The chemical relationships among water samples are starkly represented through this diagram (Walton 1970). Three well-defined fields are depicted in the Hill diagram which consists of triangular fields consisting of two in number and a one centrally located diamond-shaped field. Per cent milliequivalent per litre (\% meq/l) is the unit used for various values plotted on the diagram. The central diamond-shaped field is the region where the total characteristics of water samples are shown.

On the basis of the Piper diagram, the cation plot clearly shows that $\mathrm{Ca}^{2+}$ ion dominates the groundwater composition (with $66.6 \%$ and $50 \%$ ) in pre- and postmonsoon seasons, while there is a significant number

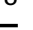




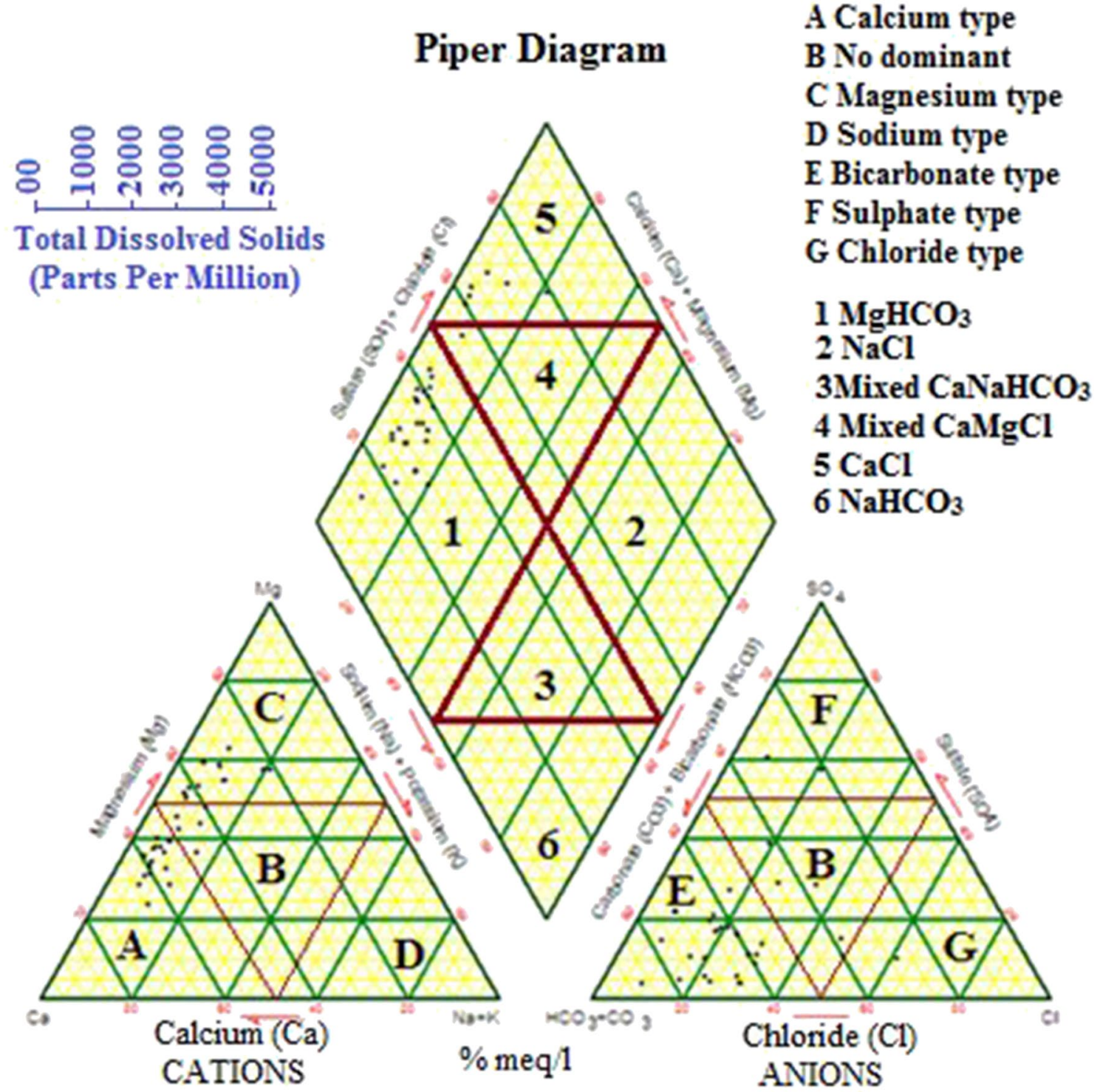

Fig. 6 Piper classification diagram illustrating the chemical composition of groundwater in post-monsoon

secondary salinity water samples are exceeding $50 \%$ and with this type which shows ion-exchange both inverse or reverse, which are the reasons for controlling the chemistry of groundwater (Davis and Dewiest 1966). However, the rest of water samples that is $26.6 \%$ in premonsoon and $20 \%$ in post-monsoon seasons are falling in $\mathrm{Ca}^{2+}-\mathrm{Mg}^{2+}-\mathrm{Cl}^{-}-\mathrm{SO}_{4}{ }^{2-}$ type simultaneously showing $\mathrm{Ca}^{2+}-\mathrm{Mg}^{2+}-\mathrm{Cl}^{-}$facies type where the dominant hydrochemical facies for either cation or anion cannot be deciphered clearly for both seasons (Todd and Mays 2005), while in the case of $\mathrm{Ca}^{2+}-\mathrm{Mg}^{2+}-\mathrm{Cl}^{-}$water type, one sample falls in this category but only in the post-monsoon season which runs parallel with the post-tourist season. The $\mathrm{Ca}^{2+}-\mathrm{Mg}^{2+}-\mathrm{Cl}^{-}$type of water and calcium chloride type of hardness is denoted where non-carbonate hardness of water exceeds more than $50 \%$ in estimation.

As per Hill-Piper diagram, it can be rightly said that the groundwater of the study area is falling in the category of $\mathrm{Ca}^{2+}-\mathrm{Mg}^{2+}-\mathrm{HCO}_{3}{ }^{-}$type and mixed type that is $\mathrm{Ca}^{2+}-\mathrm{Mg}^{2+}-\mathrm{Cl}^{-}$. As per the results of water-type classification, the natural environment of the concerned area plays an important role in dissolution of the major ions. Categorization of groundwater samples based on different facies is shown in Table 5. 
Table 5 Groundwater samples characterization based on Piper diagram

Class Groundwater types corresponding sub-divisions of facies

Samples in the different categories

\begin{tabular}{ll}
\hline Pre-monsoon & Post-monsoon \\
No. of samples (\%) & No. of samples (\%) \\
\hline $20(66.6)$ & $15(50)$ \\
$2(6.6)$ & $5(16.6)$ \\
$9(30)$ & $10(33.3)$ \\
NIL & NIL \\
$22(73.3)$ & $20(66.6)$ \\
$5(16.6)$ & $4(13.3)$ \\
2 & 2 \\
$1(3.3)$ & $1(3.3)$ \\
$21(70)$ & $20(66.6)$ \\
NIL & NIL \\
NIL & NIL \\
NIL & $1(3.3)$ \\
$8(26.6)$ & $6(20)$ \\
NIL & NIL \\
\end{tabular}

\section{Correlation matrix for analysed parameters of groundwater}

In independent and dependent variables, their extent of closeness is measured by the statistical coefficient known as correlation coefficient. When one parameter increases, the corresponding parameter increases, also termed as positive correlation, and when one parameter decreases, simultaneously the corresponding parameter decreases, also termed as negative correlation and this can be described as direct correlation relationship. The value ranges from +1 to -1 as correlation coefficient (r). When the correlation is in range of +0.8 to +1.0 and -0.8 to -1.0 , then such a relation is termed as strong. It is termed as weak when the range is from 0.0 to 0.5 and -0.0 to -0.5 . Matrix for correlation for groundwater is shown in Tables 6 and 7 for pre-monsoon and post-monsoon seasons.

- The matrix of correlation during pre-monsoon seasons shows a strong correlation of EC with TDS ( $r=0.96)$. All the dissolved solids particularly known as mineral salts in water are denoted by TDS. The higher conductivity
Table 6 Correlation matrix for groundwater samples (premonsoon)

\begin{tabular}{|c|c|c|c|c|c|c|c|c|c|c|c|c|}
\hline Parameters & $\mathrm{Ph}$ & $\mathrm{EC}$ & TDS & $\mathrm{TH}$ & $\mathrm{Ca}^{2+}$ & $\mathrm{Mg}^{2+}$ & $\mathrm{Na}^{+}$ & $\mathrm{K}^{+}$ & $\mathrm{HCO}_{3}{ }^{-}$ & $\mathrm{Cl}^{-}$ & $\mathrm{NO}_{3}^{-}$ & $\mathrm{SO}_{4}{ }^{2-}$ \\
\hline $\mathrm{pH}$ & 1.00 & & & & & & & & & & & \\
\hline EC & 0.23 & 1.00 & & & & & & & & & & \\
\hline TDS & 0.32 & 0.84 & 1.00 & & & & & & & & & \\
\hline $\mathrm{TH}$ & 0.28 & 0.20 & 0.26 & 1.00 & & & & & & & & \\
\hline $\mathrm{Ca}^{2+}$ & 0.14 & -0.42 & -0.32 & 0.60 & 1.00 & & & & & & & \\
\hline $\mathrm{Mg}^{2+}$ & 0.24 & 0.61 & 0.58 & 0.53 & -0.15 & 1.00 & & & & & & \\
\hline $\mathrm{Na}^{+}$ & 0.33 & 0.63 & 0.60 & 0.24 & -0.29 & 0.52 & 1.00 & & & & & \\
\hline $\mathrm{K}^{+}$ & 0.38 & 0.08 & 0.18 & 0.22 & 0.22 & 0.02 & 0.37 & 1.00 & & & & \\
\hline $\mathrm{HCO}_{3}^{-}$ & 0.46 & 0.12 & 0.23 & 0.21 & 0.08 & 0.13 & 0.58 & 0.36 & 1.00 & & & \\
\hline $\mathrm{Cl}^{-}$ & -0.02 & 0.15 & 0.21 & 0.35 & 0.38 & 0.00 & 0.23 & 0.34 & 0.21 & 1.00 & & \\
\hline $\mathrm{NO}_{3}^{-}$ & 0.28 & -0.15 & -0.12 & -0.25 & 0.03 & -0.27 & -0.18 & 0.50 & -0.06 & 0.02 & 1.00 & \\
\hline $\mathrm{SO}_{4}{ }^{2-}$ & 0.34 & 0.00 & -0.02 & 0.26 & 0.22 & 0.22 & 0.28 & 0.17 & 0.30 & 0.11 & 0.30 & 1.00 \\
\hline
\end{tabular}

The highlighted or bold ones are those which are above 0.5 which have some correlation level and rest below 0.5 which have very low or negligible correlations are not highlighted 
Table 7 Correlation matrix for groundwater samples (post-monsoon)

\begin{tabular}{|c|c|c|c|c|c|c|c|c|c|c|c|c|}
\hline Parameters & $\mathrm{pH}$ & EC & TDS & $\mathrm{TH}$ & $\mathrm{Ca}^{2+}$ & $\mathrm{Mg}^{2+}$ & $\mathrm{Na}^{+}$ & $\mathrm{K}^{+}$ & $\mathrm{HCO}_{3}^{-}$ & $\mathrm{Cl}^{-}$ & $\mathrm{NO}_{3}^{-}$ & $\mathrm{SO}_{4}{ }^{2-}$ \\
\hline $\mathrm{pH}$ & 1.00 & & & & & & & & & & & \\
\hline EC & 0.09 & 1.00 & & & & & & & & & & \\
\hline TDS & -0.01 & 0.96 & 1.00 & & & & & & & & & \\
\hline $\mathrm{TH}$ & -0.13 & 0.13 & 0.12 & 1.00 & & & & & & & & \\
\hline $\mathrm{Ca}^{2+}$ & -0.12 & -0.35 & -0.36 & 0.67 & 1.00 & & & & & & & \\
\hline $\mathrm{Mg}^{2+}$ & 0.09 & 0.60 & 0.54 & 0.44 & -0.18 & 1.00 & & & & & & \\
\hline $\mathrm{Na}^{+}$ & 0.03 & 0.60 & 0.60 & 0.19 & -0.25 & 0.45 & 1.00 & & & & & \\
\hline $\mathrm{K}^{+}$ & -0.31 & -0.03 & 0.01 & 0.22 & 0.30 & -0.09 & 0.35 & 1.00 & & & & \\
\hline $\mathrm{HCO}_{3}^{-}$ & 0.26 & 0.14 & 0.12 & 0.17 & 0.01 & 0.11 & 0.61 & 0.30 & 1.00 & & & \\
\hline $\mathrm{Cl}^{-}$ & -0.04 & 0.14 & 0.19 & 0.33 & 0.27 & -0.05 & 0.27 & 0.29 & 0.22 & 1.00 & & \\
\hline $\mathrm{NO}_{3}^{-}$ & -0.27 & -0.18 & -0.20 & -0.26 & 0.05 & -0.35 & -0.23 & 0.46 & -0.12 & -0.07 & 1.00 & \\
\hline $\mathrm{SO}_{4}^{2-}$ & -0.08 & 0.02 & -0.02 & 0.30 & 0.28 & 0.19 & 0.30 & 0.25 & 0.29 & 0.04 & 0.18 & 1.00 \\
\hline
\end{tabular}

The highlighted or bold ones are those which are above 0.5 which have some correlation level and rest below 0.5 which have very low or negligible correlations are not highlighted

values of water correspond with more amounts of dissolved minerals in the water body.

- The strong correlation of EC and TDS with $\mathrm{Mg}^{2+}$ ( $r=0.61$ and $r=0.58)$ and $\mathrm{Na}^{+}(r=0.63$ and $r=0.60)$ indicates the major cations controlling the water chemistry.

- There also exists a correlation which is positive between $\mathrm{TH}$ with $\mathrm{Ca}^{2+}(r=0.60)$ and $\mathrm{Mg}^{2+}(r=0.53)$, indicating the same origin and the major source of hardness in water mainly due to the salts like $\mathrm{CaCO}_{3}$ and $\mathrm{MgCO}_{3}$ (Herojeet et al. 2016).

- The significant correlation between $\mathrm{Mg}^{2+}$ with $\mathrm{Na}^{+}$ $(r=0.52)$ and $\mathrm{Na}^{+}$with $\mathrm{HCO}_{3}^{-}(r=0.58)$ shows processes of various ion-exchanges, and rock minerals are naturally weathering in the aquifer system. The correlation of $\mathrm{HCO}_{3}^{-}$with $\mathrm{Na}^{+}$relates to natural processes, whereas $\mathrm{NO}_{3}{ }^{-}$with $\mathrm{K}^{+}$has to be related with humaninduced activities (Srivastava and Ramanathan 2008; Okiongbo and Douglas 2015).

- In post-monsoon season, the correlation matrix shows that correlation is positive between EC and TDS with correlation coefficient $(r)$ 0.96. Both TDS and EC have a correlation which is positive with $\mathrm{Mg}^{2+}(r=0.60$ and $0.54)$ and $\mathrm{Na}^{+}(r=0.60$ and 0.60$)$, indicating weathering of bedrocks minerals.

\section{Suitability of groundwater for irrigation}

1. Water is an easily assessable resource where human being is utilizing it for different purposes depending on their necessity. The process of irrigation causes recharging of water present in the soil of root zone of the plants. In this process, source of water is due to human inter- vention rather than the natural media of precipitation in the form of rainfall and snowfall. For every variation in water usage, it is required that it meets the optimum quality of water, and the techniques and methods for water quality analysis should be of the standard and well-tested methodologies (Babiker 2007). Irrigation water quality varies substantially depending principally upon the salinity, soil permeability, toxicity and some miscellaneous concerns such as loading of excessive amounts of nitrogen or if the variation of $\mathrm{pH}$ of water is unusual like very abrupt increase or decrease. The important factor for elucidating the irrigation quality of water is the chemical quality of water (Gupta 1989). The extent of suitability of water for irrigation purposes is determined by the composition and concentration of its constituents dissolved in it. On both soils and plants, irrigation suitability is dependent on some major constituents of minerals dissolved in that water (Wilcox 1955a, b). Some parameters which determine the suitability for irrigation of 30 groundwater samples are determined by (1) (EC) Electrical conductivity, (2) (SAR) sodium adsorption ratio, (3) US salinity diagram (4) (\% Na) per cent sodium, (5) (RSC) residual sodium carbonate, as shown in Table 8.

Classification on four irrigation parameters is shown in Table 9 which shows that:

(1) Electrical conductivity Total dissolved solids (TDS) or total dissolved ions is measured by (EC) electrical conductivity of the given water media. One of the major concerning factors for determining irrigation quality of water is its concentration of excessive salt content. If the soil and climatic conditions along with regular 
Table 8 Irrigation quality parameters for groundwater

\begin{tabular}{|c|c|c|c|c|c|c|c|c|c|}
\hline \multirow[t]{2}{*}{ S. no. } & \multirow[t]{2}{*}{ Location } & \multicolumn{4}{|c|}{ Pre-monsoon } & \multicolumn{4}{|c|}{ Post-monsoon } \\
\hline & & $\mathrm{EC}$ & SAR & $\% \mathrm{Na}$ & RSC & $\mathrm{EC}$ & SAR & $\% \mathrm{Na}$ & RSC \\
\hline 1 & Gyalung & 223 & 1.03 & 10.13 & -2.64 & 220 & 1.00 & 10.70 & -2.53 \\
\hline 2 & Gangles & 210 & 1.31 & 9.33 & -3.93 & 190 & 1.30 & 8.88 & -4.00 \\
\hline 3 & Gompa & 283 & 1.12 & 11.25 & -3.43 & 260 & 1.10 & 11.72 & -3.35 \\
\hline 4 & Sankar & 205 & 0.99 & 12.76 & -2.30 & 201 & 0.97 & 12.94 & -2.36 \\
\hline 5 & Yourtung & 234 & 1.47 & 7.44 & -4.84 & 220 & 1.43 & 7.73 & -4.61 \\
\hline 6 & Khagshal & 256 & 1.71 & 13.89 & -2.87 & 270 & 1.63 & 14.76 & -2.70 \\
\hline 7 & Changspa & 287 & 1.19 & 8.64 & -3.67 & 280 & 1.12 & 8.28 & -3.52 \\
\hline 8 & Chubi & 248 & 1.20 & 18.80 & -1.21 & 220 & 1.09 & 21.41 & -0.80 \\
\hline 9 & LEDeG & 275 & 1.11 & 8.57 & -2.87 & 262 & 1.01 & 9.61 & -2.46 \\
\hline 10 & Karzoo & 303 & 1.10 & 9.64 & -3.12 & 300 & 1.02 & 10.04 & -2.83 \\
\hline 11 & U.Tuckha & 439 & 0.98 & 10.23 & -1.17 & 400 & 0.93 & 9.72 & -1.12 \\
\hline 12 & Middle Sch & 387 & 1.57 & 6.19 & -5.13 & 340 & 1.63 & 6.33 & -5.34 \\
\hline 13 & Fort Road & 549 & 1.54 & 9.22 & -4.41 & 529 & 1.58 & 8.69 & -4.72 \\
\hline 14 & Shenam & 324 & 1.28 & 10.60 & -3.39 & 365 & 1.32 & 9.76 & -3.63 \\
\hline 15 & 16BRTF & 295 & 1.30 & 18.20 & -1.87 & 286 & 1.22 & 18.18 & -1.67 \\
\hline 16 & Zorawar Ft & 424 & 1.23 & 12.05 & -2.64 & 387 & 1.18 & 11.68 & -2.57 \\
\hline 17 & Skara Spring & 575 & 1.37 & 15.58 & -3.47 & 556 & 1.34 & 14.88 & -3.45 \\
\hline 18 & Skalzangling & 403 & 1.15 & 15.45 & -2.63 & 390 & 1.16 & 15.55 & -2.64 \\
\hline 19 & Housing $\mathrm{Cl}$ & 849 & 1.68 & 17.34 & -4.24 & 826 & 1.53 & 17.04 & -3.92 \\
\hline 20 & DIHAR & 660 & 1.43 & 15.55 & -2.80 & 568 & 1.38 & 14.88 & -2.69 \\
\hline 21 & Murtse & 357 & 1.18 & 10.44 & -3.19 & 360 & 1.22 & 10.21 & -3.34 \\
\hline 22 & Ibex Colony & 423 & 1.32 & 8.45 & -4.04 & 411 & 1.22 & 8.47 & -3.69 \\
\hline 23 & ITBP Leh & 351 & 1.57 & 9.98 & -3.50 & 302 & 1.53 & 9.68 & -3.39 \\
\hline 24 & MES IIIrd & 347 & 1.25 & 8.21 & -2.79 & 321 & 1.19 & 8.17 & -2.66 \\
\hline 25 & MES Spituk & 482 & 1.53 & 11.17 & -3.29 & 461 & 1.40 & 11.39 & -2.80 \\
\hline 26 & Airforce Stn & 200 & 1.20 & 9.70 & -2.68 & 210 & 1.24 & 9.75 & -2.85 \\
\hline 27 & CIBS & 301 & 1.63 & 7.95 & -4.14 & 501 & 1.53 & 9.05 & -3.60 \\
\hline 28 & Zivey Tsal & 835 & 1.81 & 30.06 & -1.81 & 820 & 1.67 & 28.72 & -1.66 \\
\hline 29 & Choglamsar & 496 & 1.68 & 18.34 & -2.44 & 488 & 1.53 & 18.42 & -1.96 \\
\hline 30 & SOS Village & 367 & 1.49 & 2.76 & -3.29 & 356 & 2.02 & 18.00 & -3.09 \\
\hline
\end{tabular}

cultural practices remain stagnant regarding irrigation practices, a higher measure of EC will result in a higher rate of salinity hazard for the growing crops. The EC of irrigation water is often denoted as $\mathrm{EC} w$.

Out of total 30 samples, $20 \%$ lie in excellent quality during both pre-monsoon and post-monsoon seasons, while $73.3 \%$ samples of water lie in good quality during both pre-monsoon and post-monsoon seasons. The remaining $6.6 \%$ samples fall in fair category. The absorption of nutrients and water from the soil is interrupted due to high level of EC as a result of reduction in the general osmotic activity level of plants growing in such irrigated water (Saleh et al. 1999).

(2) (Sodium adsorption ratio) SAR All 100\% samples that is total 30 samples of groundwater lie in excellent quality during both pre-monsoon and post-monsoon seasons.
Sodium Hazard is expressed in terms of sodium adsorption ratio (Gholami and Srikantaswamy 2009). The hazard or danger due to excessive concentration of sodium ions is estimated by sodium adsorption ratio (SAR). The suitability of water for irrigation purposes is determined by SAR, and this value is evaluated by ratio of $\mathrm{Na}^{+}$ions concentration over square root sum of $\mathrm{Ca}^{2+}$ and $\mathrm{Mg}^{2+}$ ions concentration divided by 2 in a sample of water. The SAR equation (Hem 1991) is mentioned hereunder:

SAR $=\frac{\mathrm{Na}^{+}}{\left(\frac{\sqrt{\mathrm{Ca}^{2+}+\mathrm{Mg}^{2+}}}{2}\right)} \quad$ (all units in meq/l)

If the concentration of $\mathrm{Na}^{+}$ions is high and $\mathrm{Ca}^{2+}$ ions is low, then $\mathrm{Na}^{+}$ions gets filled up in the complex of ion-exchange, and ultimately the structure of soil gets 
Table 9 Different criteria of water suitability for irrigation purposes

\begin{tabular}{|c|c|c|c|c|c|}
\hline \multirow[t]{3}{*}{ S. no. } & \multirow[t]{3}{*}{ Parameters } & \multirow[t]{3}{*}{ Values } & \multirow[t]{3}{*}{ Water class } & \multicolumn{2}{|l|}{ Groundwater } \\
\hline & & & & \multicolumn{2}{|c|}{$\begin{array}{l}\text { No. of samples (percentage of } \\
\text { samples) }\end{array}$} \\
\hline & & & & Pre-monsoon & Post-monsoon \\
\hline \multirow[t]{4}{*}{1.} & \multirow[t]{4}{*}{$\mathrm{EC}(\mu \mathrm{S} / \mathrm{cm})(\mathrm{USSL} 1954)$} & $<250$ & Excellent & $6(20)$ & $6(20)$ \\
\hline & & $250-750$ & Good & $22(73.3)$ & $22(73.3)$ \\
\hline & & $750-2250$ & Fair & $2(6.6)$ & $2(6.6)$ \\
\hline & & $>2250$ & Poor & NIL & NIL \\
\hline \multirow[t]{4}{*}{2.} & \multirow[t]{4}{*}{ SAR (Todd 1959) } & 10 & Excellent & $30(100)$ & $30(100)$ \\
\hline & & $10-18$ & Good & NIL & NIL \\
\hline & & $18-26$ & Doubtful & NIL & NIL \\
\hline & & $>26$ & Unsuitable & NIL & NIL \\
\hline \multirow[t]{5}{*}{3.} & \multirow[t]{5}{*}{ \% Na (Wilcox 1955) } & $<20$ & Excellent & $29(96.6)$ & $28(93.3)$ \\
\hline & & $20-40$ & Good & $1(3.3)$ & $2(6.6)$ \\
\hline & & $40-60$ & Permissible & NIL & $3(5)$ \\
\hline & & $60-80$ & Doubtful & NIL & NIL \\
\hline & & $>80$ & Unsuitable & NIL & NIL \\
\hline \multirow[t]{3}{*}{4.} & \multirow[t]{3}{*}{ RSC (meq/l) (Eaton 1950) } & $<1.25$ & Water can be used safely & $30(100)$ & $30(100)$ \\
\hline & & $1.25-1.5$ & Can be used with management & NIL & NIL \\
\hline & & $>2.5$ & Unsuitable for better yields & NIL & NIL \\
\hline
\end{tabular}

destroyed as the clay particles in the soil content gets dispersed (Todd 1980). So, the growth ability of plants is eventually affected.

(3) US salinity diagram

Another valid measure to fathom salinity hazard is the level of conductance. The osmotic activity of plants reduces with the increasing salinity gradient of soil where it grows (Subramani et al. 2005). In simpler terms, the plants are not able to absorb as much water which is required due to the presence of large concentration of ions in soil which retains the irrigated water. So, ultimately the water available or required for the plants reduces. With respect to EC and SAR values, the US Salinity Laboratory (USSL) classification of groundwater was undertaken for 30 groundwater samples (Table 9). According to the 30 groundwater samples of study area after plotting it on the USSL diagram, both during pre-monsoon and post-monsoon seasons, during the season of pre-monsoon, six samples lie in the field of C1S1, two samples in C3S1, while the rest 22 samples in $\mathrm{C} 2 \mathrm{~S} 1$. Accordingly during postmonsoon season, three samples lie in C1S1 field, two samples in C3S1 field and the rest 25 samples in C2S1 field (Fig. 7). Hence, quality of water in the area concerned is satisfactory for the purpose of irrigation use in almost all soil types with a slight chance of developing harmful levels of exchangeable sodium.

(4) Per cent sodium (\% $\mathrm{Na}$ ) With respect to calcium and magnesium ions concentration, if the concentration of
$\mathrm{Na}^{+}$ions is in excess, there occurs reduction in the level of permeability of soil. This occurs due to absorption of $\mathrm{Na}^{+}$ions by clay particles instead of $\mathrm{Mg}^{2+}$ ions and $\mathrm{Ca}^{2+}$ ions, thus inhibiting supply of water required for the crops. Calcium and magnesium have the tendency to flocculate the soil particles rendering looseness in the soil and enhance good penetration of water and air. On the other hand, sodium causes deflocculation and prevents free movement of water. The sodium percentage $(\% \mathrm{Na})$ is calculated using the following formula given by Wilcox (1955a, b):

$\% \mathrm{Na}=\frac{\mathrm{Na}^{+}+\mathrm{K}^{+}}{\mathrm{Ca}^{2+}+\mathrm{Mg}^{2+}+\mathrm{Na}^{+}+\mathrm{K}^{+}} * 100 \quad$ (all units in meq/l)

Against the values of EC in Wilcox diagrams, the calculated values of groundwater for $\% \mathrm{Na}$ in the area are plotted (Fig. 8)

According to this parameter, $96.6 \%$ and $93.3 \%$ samples out of total 30 groundwater samples during preand post-monsoon seasons, respectively, lie in excellent quality of water, while the remaining $3.3 \%$ and $6.6 \%$ during pre- and post-monsoon seasons, respectively, lie in good quality of water. Thus, all samples of groundwater lie in purview of water quality which is excellent to good and are fit for purposes of irrigation.

(5) Residual sodium carbonate (RSC) The suitability of water for purposes of irrigation is dependent on many factors, one vital phenomenon being the increase in 


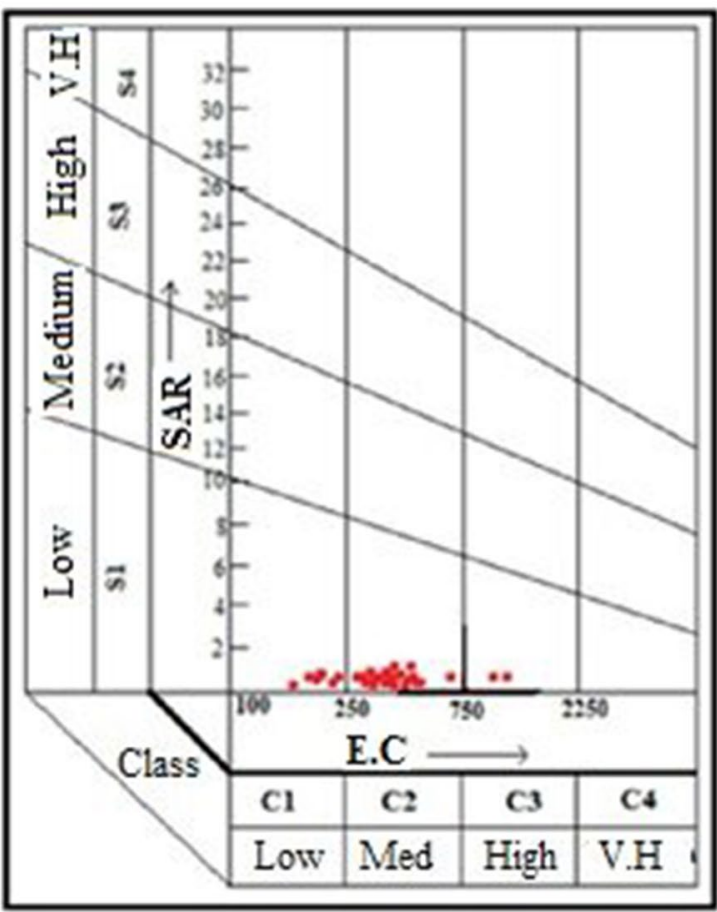

Pre Monsoon

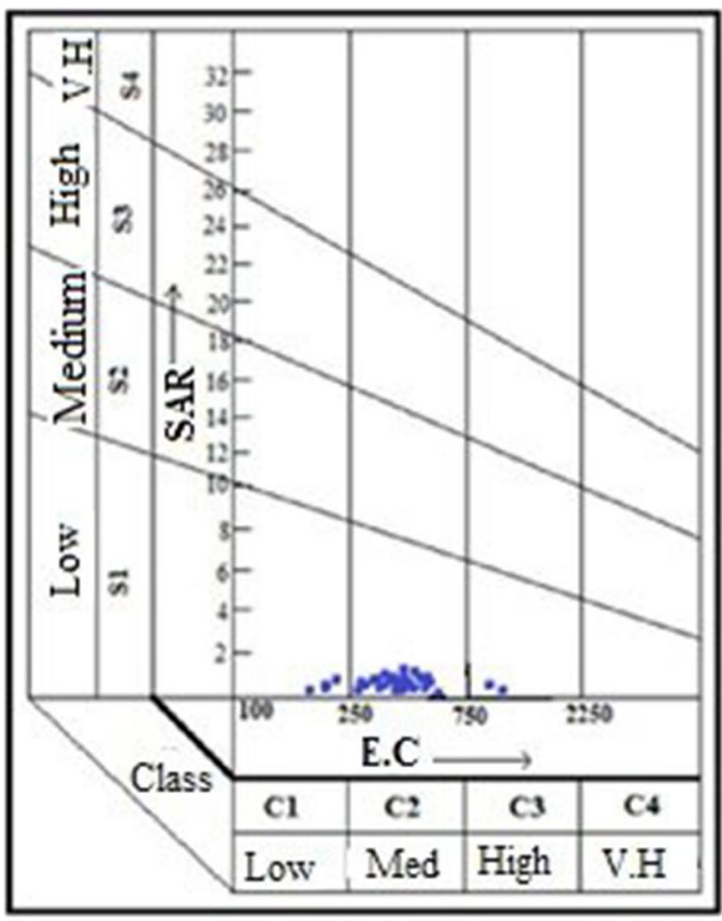

V.H means Very High

Post Monsoon

Fig. 7 USSL classification of groundwater in the study area

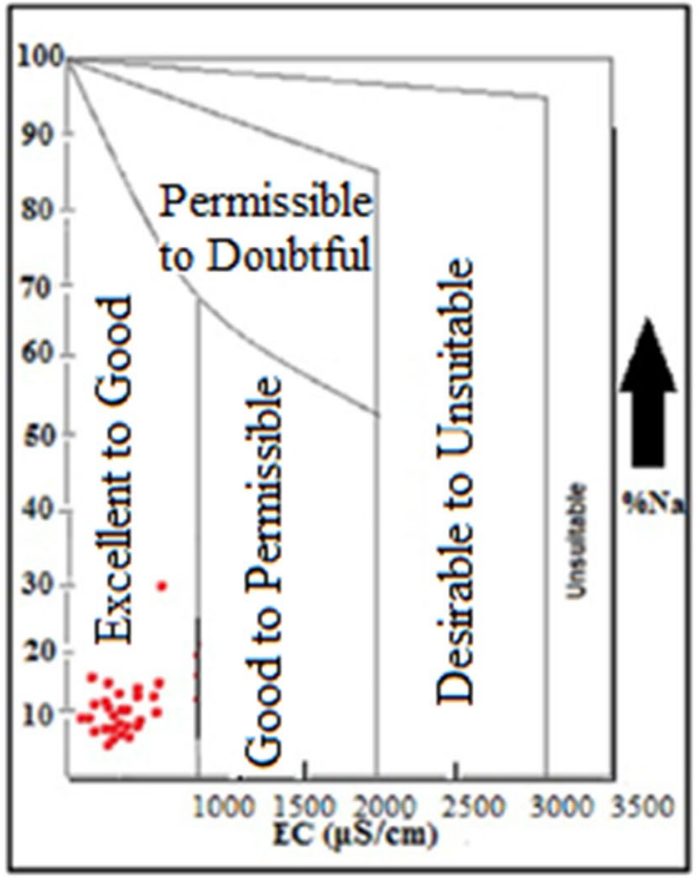

Pre Monsoon

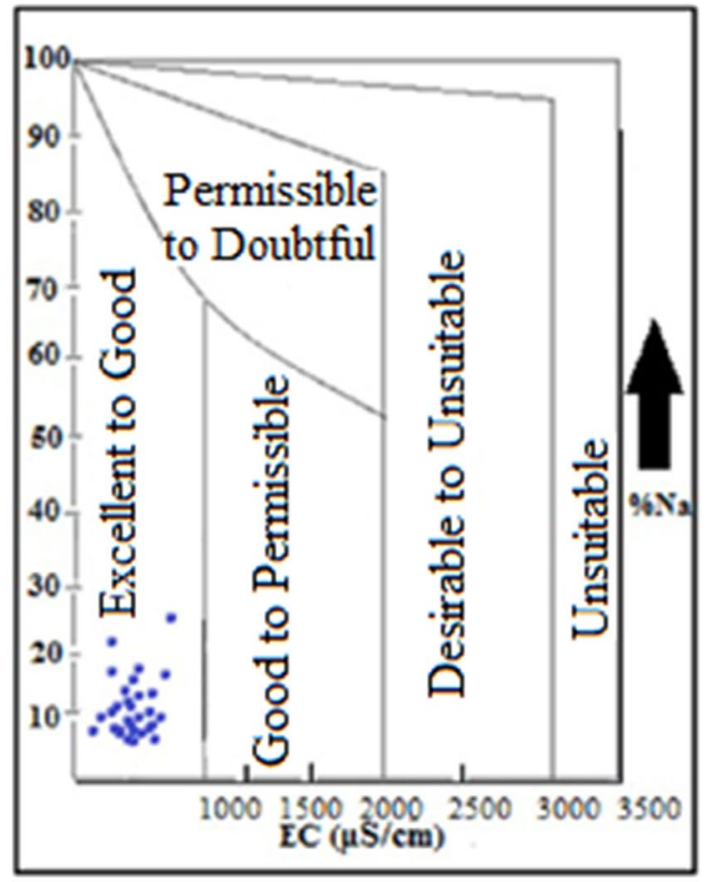

Post Monsoon

Fig. 8 Wilcox diagram of groundwater in the study area 
concentration of carbonate ions and bicarbonate ions over the total sum of concentration of magnesium ions and calcium ions. When the water meant for irrigation uses has $\mathrm{HCO}_{3}{ }^{-}$ions and $\mathrm{CO}_{3}{ }^{2-}$ ions in excess, then this alkaline water has an affinity for the ions of $\mathrm{Ca}^{2+}$ ions and $\mathrm{Mg}^{2+}$ ions to undergo precipitation, as the concentration levels of irrigation water in soil increase. Irrigation water with high RSC is regarded deleterious towards the physical attributes of soils, as it decreases the overall soil permeability. Eventually, the level of sodium increases in form of sodium carbonate and this is denoted by RSC which is evaluated by the equation (Eaton 1950):

$\mathrm{RSC}=\left(\mathrm{CO}_{3}^{2-}+\mathrm{HCO}_{3}^{-}\right)-\left(\mathrm{Ca}^{2+}+\mathrm{Mg}^{2+}\right) \quad($ all units in meq/l $)$

Out of total 30 groundwater samples, all 100\% lie in excellent quality during pre-monsoon and post-monsoon seasons.

Funding Funding was provided by University Grants Commission (Grant No. UGC/JRF, June 2010).

Open Access This article is licensed under a Creative Commons Attribution 4.0 International License, which permits use, sharing, adaptation, distribution and reproduction in any medium or format, as long as you give appropriate credit to the original author(s) and the source, provide a link to the Creative Commons licence, and indicate if changes were made. The images or other third party material in this article are included in the article's Creative Commons licence, unless indicated otherwise in a credit line to the material. If material is not included in the article's Creative Commons licence and your intended use is not permitted by statutory regulation or exceeds the permitted use, you will need to obtain permission directly from the copyright holder. To view a copy of this licence, visit http://creativecommons.org/licenses/by/4.0/.

\section{References}

CGWB (2009) Ground water information booklet of Leh District, Jammu and Kashmir State form Anonymous (2008)

APHA (2005) Standard methods for the examination of water and wastewater, 21st edn. American Public and Health Association, Washington

Babiker IS, Mohamed MAA, Hiyama T (2007) Assessing groundwater quality using GIS. Water Resour Manag 21:699-715

Ballabh B, Chaurasia OP, Pande PC, Ahmed Z (2007) Raw edible plants of cold desert Ladakh. Indian J Tradit Knowl 6(1):182-184

Davis SN, Dewiest RJM (1966) Hydrogeology. John Wiley and Sons Inc., New York, USA, pp 1-463

Dolma K, Rishi MS, Lata R (2015) Evaluation of groundwater quality and its suitability for drinking purposes-a case of Leh Town, Ladakh (J\&K), India. Int J Sci Eng Res 6(5):576-590

Eaton FM (1950) Significance of carbonates in irrigation waters. Soil Sci 39:123-133

Fewkes JH (2012) Living in the material world: cosmopolitanism and trade in early twentieth century Ladakh. Mod Asian Stud 46:261p
Gairola S, Sharma J, Pedi YS (2014) A cross-cultural analysis of Jammu, Kashmir and Ladakh (India) medicinal plant use. J Ethnopharmacol 155:925-986

Gholami S, Srikantaswamy S (2009) Analysis of agricultural impact on the cauvery river water around KRS dam. World Appl Sci J 6(8):1157-1169

Gibbs RJ (1970) Mechanism controlling world water chemistry. Science 170:1088-1090

Gupta DC (1989) Irrigational suitability of surface water for agricultural development of the area around Mandu, District Dhar, Madhya Pradesh, India. J Appl Hydrol 2(2):63-71

Hem JD (1991) Study and Interpretation of the Chemical Characteristics of Natural Waters. Scientific Publishers, Jodhpur

Herojeet RK, Madhuri SR, Renu L, Ranjna G (2016) Application of environmetrics statistical models and water quality index for groundwater quality characterization of alluvial aquifer of Nalagarh Valley, Himachal Pradesh, India. Sustain Water Resour Manag 2:39-53. https://doi.org/10.1007/s40899-015-0039-y

Jina PS (1994) Tourism in Ladakh Himalaya. Indus Publishing Company, New Delhi, pp 1-212

Joshi PK, Rawat GS, Padaliya H, Roy RS (2005) Land use/land cover identification in an alpine and arid region (Nubra Valley, Ladakh) using satellite remote sensing. J Indian Soc Remote Sens 33(3):371-380

Joshi PK, Rawat GS, Padaliya H, Roy RS (2006) Biodiversity characterization in Nubra Valley, Ladakh with special reference to plant resource conservation and bioprospecting. Biodivers Conserv $15: 4253-4270$

Kishore S (2013) Beyond cinephilia. Third Text 27(6):735-746

Okiongbo KS, Douglas RK (2015) Evaluation of major factors influencing the geochemistry of groundwater using graphical and multivariate statistical methods in Yenagoa city, Southern Nigeria. Appl Water Sci 5:27-37. https://doi.org/10.1007/s1320 1-014-0166-x

Ophori DU, Toth J (1989) Patterns of groundwater chemistry, Ross Creek Basin, Canada. Groundwater 27:20-26

Pant RK, Phadtare NR, Chamyal LS, Juyal N (2005) Quaternary deposits in Ladakh and Karakoram Himalaya: a treasure trove of the palaeoclimate records. Curr Sci 88(11):1789-1798

Piper AM (1944) A geographic procedure in the geochemical interpretation of water analysis. Trans Am Geophys Union 25:914-928

Rao NS (2007) Groundwater quality as a factor for identification of recharge zones. Environ Geosci 14:79-90

Saleh A, Al-Ruwaih F, Shehata M (1999) Hydrogeochemical processes operating within the main aquifers of Kuwait. J Arid Environ 42:195-209

Soltan ME (1998) Characterisation, Classification, and Evaluation of Some Groundwater Samples in Upper Egypt. Chemosphere 37(4):735-745

Srivastava SK, Ramanathan AL (2008) Geochemical assessment of groundwater quality in vicinity of Bhalswa Landfill, Delhi, India, using graphical and multivariate statistical methods. Environ Geol 53:1509-1528

Statistical Hand Book (2015-16) District Statistics and Evaluation Office. Ladakh Autonomous Hill Development Council (LAHDC), Leh, vol 36, pp 1-156

Subramani T, Elango L, Damodarasamy SR (2005) Groundwater quality and its suitability for drinking and agricultural use in Chithar River Basin, Tamil Nadu, India. Environ Geol 47:1099-1110

Todd DK (1959) Groundwater Hydrology. Wiley, New York

Todd DK (1980) Groundwater hydrology. Wiley, New York, p 535

Todd DK, Mays LW (2005) Groundwater hydrology. Wiley, New York, pp 1-636

U.S. Salinity Laboratory (1954) Diagnosis and improvement of saline and alkaline soils. Hand Book No. 60. U.S. Dept. of Agriculture, p. 160 
Walton WC (1970) Classification and use of irrigation waters. U.S. Department of Agriculture Circular no. 969, p 19

Wilcox LV (1955a) Classification and use of irrigation waters. US

Department of Agriculture Circular No. 969, pp 1-19

Wilcox LV (1955b) Classification and use of irrigation water. US Dept. of Agriculture Cir. No. 969, Washington, p 19
Publisher's Note Springer Nature remains neutral with regard to jurisdictional claims in published maps and institutional affiliations. 